\title{
Possible Ways of Renewal in a Touristic Destination: A Case for Integrated Destination Development in Hungary. The case of Orfú
}

\author{
Tibor Gonda $^{\mathbf{1}}$ (iD), Antal Aubert ${ }^{2}$ (iD, Mónika Jónás-Berki ${ }^{2}$ (D) Andrea Pálfi $^{2}$ \\ ${ }^{1}$ Faculty of Economics Marketing and Tourism Institute, University of Pécs, H-7622 Pécs, Rákóczi út 80, Hungary; \\ gonda.tibor@ktk.pte.hu \\ ${ }^{2}$ Faculty of Sciences, Institute of Geography, Department of Tourism, University of Pécs, H-7624 Pécs, \\ Ifjúság útja 6, Hungary; \\ aubert@ttk.pte.hu (A.A.); berkim@gamma.ttk.pte.hu (M.J-B); palfia@gamma.ttk.pte.hu (A.P.)
}

Received: 24 October 2020; Revised: 30 November 2020; Accepted: 11 December 2020;

Published online: 15 December 2020

\begin{abstract}
The paper demonstrates the complex issue of the life cycle and renewal of destinations by the example of a destination in Hungary. These days, due to the ever increasing competition among destinations both in domestic and international markets, this is the central issue in the development and management of destinations, especially where recreational and excursionist functions are dominant. The target area chosen can be found in the hinterland of a regional centre, where, in addition to recreational functions, the repositioning efforts of the last ten years led to the more and more important role of sport tourism and supplementary tourism products like ecotourism, heritage tourism and festival tourism. This versatility means another challenge for the actors of the destination, as the main pillars of the renewal of the destination concern all actors in the destination (inhabitants, non-governmental organisations, service providers, and local authority) in some way. During the research thus authors also carried out a questionnaire survey with the local stakeholders (inhabitants, local authority and actors interested in tourism, e.g. holiday home owners, service providers), in addition to the processing of secondary data sources.
\end{abstract}

Key words: destination management, destination life cycle, renewal, Hungary, Orfú

Citation: Gonda, T., Aubert, A., Jónás-Berki, M., \& Pálfi, A. (2020). Possible Ways of Renewal in a Touristic Destination: A Case for Integrated Destination Development in Hungary. The Case of Orfü. Central European Journal of Geography and Sustainable Development, 2(2), 24-37. https://doi.org/10.47246/CEJGSD.2020.2.2.3

\section{| Full text $\mid$}

